\title{
The Use of Phytase and Acidifier Supplementation on Growth and Feed Utilization of Tra Catfish (Pangasianodon Hypophthalmus)
}

\author{
Hung Le Thanh ${ }^{1, *}$, Vo Thi Thanh Binh ${ }^{1}$, Wayoon Poonperm ${ }^{2}$, Peter Ader \\ ${ }^{1}$ Faculty of Fisheries, Nong Lam University, Vietnam \\ ${ }^{2}$ BASF Thailand Ltd., Thailand \\ ${ }^{3}$ BASF SE Germany, Germany
}

Copyright $\bigcirc 2017$ by authors, all rights reserved. Authors agree that this article remains permanently open access under the terms of the Creative Commons Attribution License 4.0 International License

\begin{abstract}
In the study five iso-nitrogenous and iso-energetic diets were formulated. T1 was a control with DCP (di-calcium phosphate) supplementation, T2 without DCP, T3 was a T2 supplemented with Acidifier $(0.3 \%$ formic acid), T4 was a T2 supplemented with phytase (750 FTU/kg) and T5 was a T2 supplemented with Acidifier and phytase. Tra catfish fingerlings $(15 \mathrm{~g})$ were cultured in 500 liter composite tanks in 10 weeks. The study indicates dietary supplementation of phytase (T4 and T5) significantly improved growth performances, ameliorated feed utilization and increased ash content of the whole body and bone phosphorus of juvenile Tra catfish. The study also indicates supplementing acidifier also improved growth performance, ameliorated feed utilization and increased ash content of the whole body and bone phosphorus. The decreased $\mathrm{pH}$ value of gastric juice due to the acidifier supplementation can accounts for the present result. However, mixture of phytase and an acidifier in T5 treatment does not have any ameliorated effect when compared to the separated phytase or separated acidifier. It seems the synergic effect of a mixture does not exist in the study. Some studies are needed to find out the suitable mixture of the two feed additives in Tra catfish feed.
\end{abstract}

Keywords Phytase, Acidifier, Tra Catfish (Pangasianodon Hypophthalmus)

\section{Introduction}

Phytase is an enzyme specific to hydrolyze indigestible phytate, commonly existing in plant protein source, has been increasingly used in aqua feed in the last two decades for the fear of phosphorus pollution to the aquatic environment [4, 6]. Phytase supplementation in aqua feed also improves the availability of other trace elements $[1,4,6,9,14,20]$
Several studies have demonstrated that use of phytase in aqua feed can release bound phosphorus to meet requirements of several fish species such as tilapia $[16,18]$, channel catfish [12,15], carp [18,21,22], Pangasius pangasius [6] and Pangasius bocourti[13].

Tra catfish (Pangasianodon hypophthalmus) has been intensively cultured in Mekong delta Vietnam. The annual production obtained 1.35 million tons in 2010 [23]. Feed for the species are mainly from plant protein sources, and phosphorus demand is normally met by DCP and MCP supplementation [10].

The objectives of the study was to evaluate the supplementation of a phytase enzyme to replace DCP and if the effect of non-corrosive acidifier (formic acid and sodium formate) can boost the phosphorus digestibility in tra catfish feed.

\section{Materials and Methods}

\subsection{Feed and Feeding}

Five iso-nitrogenous and iso-energetic diets, based on a commercial formulation, are utilized in the experiment. The feed are produced in a feed mill and extruded $\left(120-130^{\circ} \mathrm{C}\right)$ to make a floating feed. Feed ingredients (Table 1) contain fishmeal, soybean meal, rice bran, defatted rice bran, cassava meal, vitamin and mineral premix. Protein and fat content of the final five diets were formulated to be $28 \%$ and $6 \%$, respectively.

In feed ingredients, fish oil $(2.2 \%)$ was not added in the feed processing but it was top dressed on the extruded feed after the feed was processed. Enzyme preparation of phytase (Natuphos ${ }^{\circledR} 5000$ CombiL of BASF company) and the acidifier (Amasil ${ }^{\circledR}$ NA of BASF company) were sprayed to the extruded feed according to designed treatments in Table 2 . 
Table 1. Feed ingredients to formulate experimental diets

\begin{tabular}{|c|c|c|c|}
\hline No. & Composition & Feed A (with DCP) & Feed B(without DCP) \\
\hline 1 & Defatted rice bran & 10.00 & 22.00 \\
\hline 2 & Dry rice bran & 20.50 & 5.00 \\
\hline 3 & Fishmeal 58\% & 5.00 & 45.20 \\
\hline 4 & Soybean meal & 45.70 & 15.00 \\
\hline 5 & Cassava meal & 15.00 & 2.20 \\
\hline 6 & Fish oil & 2.20 & 0.15 \\
\hline 7 & DL-Methionine & 0.15 & - \\
\hline 8 & Di-calcium phosphate (DCP) & 1.20 & 0.25 \\
\hline 9 & Premix vitamin \& mineral & 0.25 & 100.00 \\
\hline
\end{tabular}

Table 2. Feeding trial design

\begin{tabular}{|c|c|}
\hline Treatment & Condition \\
\hline $\mathrm{T} 1$ (Control) & $\begin{array}{l}\text { Feed A with DCP supplementation so that the available phosphorus was balanced at } 0.5 \% \text { for phosphorus } \\
\text { requirement }\end{array}$ \\
\hline $\mathrm{T} 2$ & Feed B without DCP supplementation \\
\hline $\mathrm{T} 3$ & Feed B + Acidifier (formic acid and sodium formate) $0.3 \%$ Amasil $^{\mathbb{E}} \mathrm{NA}$, product of BASF \\
\hline $\mathrm{T} 4$ & Feed B + Phytase (Natuphos ${ }^{\circledR} 5000$ CombiL $(150 \mathrm{~g} / \mathrm{MT}) *$ product of BASF \\
\hline T5 & Feed B + Natuphos ${ }^{\circledR} 5000$ CombiL $(150 \mathrm{~g} / \mathrm{MT})^{*}+0.3 \%$ Amasil $^{\circledR} \mathrm{NA}$ \\
\hline
\end{tabular}

* 150g/MT are equivalent to: 750 FTU of 3-phytase, 840 TXU of endo-1,4- 3 -xylanase and 375 TGU of endo-1,4-ß-glucanase)

\subsection{Fingerlings and Facilitators}

Tra catfish fingerlings (4-5g) in Mekong delta provinces was transported to Nong Lam University experimental farm. The fish was acclimated to the confined condition in tanks for 2 weeks and feed a commercial diet twice daily. Before starting the experiment, fish was screened for homogenous weight and experimentally cultured in outdoor composite tanks (500 liter). Each tank contains 45 fish on average $15 \mathrm{~g}$. The fish was fed experimental feed in 10 weeks in order to evaluate the effectives of enzyme and feed additive on fish growth and feed utilization. . There were five diets with four replicates. Therefore, twenty tanks were used in the trial. Tanks were placed outdoors and water was supplied from an earthen pond $(500 \mathrm{~m} 2)$ and daily exchanged.

Feed was distributed twice a day and fed at satiation: one meal in the morning at 9.00 and one meal in the afternoon at 15.00. One hour after feeding the unfed feed was collected and dried to calculate daily consumed feed for each tank. Feed intake was registered daily to compare the feeding intake of five diets at the end of the experiment. During the feeding trial, water quality in 20 tanks was monitored. Water temperature and $\mathrm{pH}$ were daily monitored in the morning and in the afternoon. Dissolved oxygen and total ammonia were weekly checked.

\subsection{Evaluate Growth Performances and Feed Utilization}

Evaluation of growth performances and feed utilization of fish fed five experimental diets, Initial fish weight was measured at the beginning of the trial. At the end of the experiment, fish weight was also measured by batch and fish number was counted to evaluate the survival. The specific growth rate, daily weight gain, survival, and feed conversion ratio were calculated as follows;

- $\quad$ Specific growth rates (SGR)

$$
S G R=\frac{(\operatorname{Ln} W 2-\operatorname{Ln} W 1)}{T 2-T 1} X 100 \% / \mathrm{day}^{-1}
$$

in which

- W2: Mean weight at the end of the experiment

- W1:Mean weight at the beginning of the experiment

- T2- T1: Duration of the experiment

In the study, feed efficiency utilization was monitored using the feed conversion ratio (FCR) and protein efficiency ratio (PER) as follows

- $\quad$ Feed conversion rate (FCR)

- $\quad \mathrm{FCR}=$ Total feed intake/ Fish growth (W2-W1)

in which

Mortality in each tank will be recorded on a daily basis during the whole experimental period in order to calculate survival rate:

- Survival rate $=N / N_{0} \times 100 \%$

$\mathrm{N}_{0}=$ number of fishes at the start of the study

$\mathrm{N}=$ number of fishes at the end of the study

- Feed intake

Feed intake (FI) in each tank will be registered and the measure as follows

$F I=$ Total feed intake/total fish $(g / f i s h / d a y)$ 


\subsection{Evaluate Bone Mineralization and Digestibility on Protein and Phosphorus}

At the end of the feeding trial, 10 fish per composite tank (total 20 tanks) were collected for carcass analysis for total mineral, calcium and phosphorus. And the fish bone was also be analyzed on mineral, calcium and phosphorus.

After termination of the growth performance trial (week 10 onwards), 20 remaining fish in each tank were subjected to the digestibility trial (the fish were acclimatized with normal experimental feed for 3-4 days and changed to chromic oxide supplemented test diet for at least 7 days before start of the faeces collection (week-12). Protein and phosphorus digestibility of the fish in each treatment were determined by feeding the fish with experimental feed added with $0.5 \%$ chromic oxide for 7-10 days, and analysis of protein and chromic oxide content in fish faeces.

Apparent digestibility coefficient (ADC) of dry matter and nutrient was determined as following equations:

- $\quad$ ADC of dry mater $=100 \times[1-(\mathrm{C} / \mathrm{D})]$

- $\mathrm{ADC}$ of nutrients $=100 \times\{1-[\mathrm{A} / \mathrm{B})] \times[(\mathrm{C} / \mathrm{D})]\}$.

Where $\mathrm{A}$ and $\mathrm{B}$ are nutrient concentration (\%) in faeces and feed, $\mathrm{C}$ and $\mathrm{D}$ are concentration (\%) of $\mathrm{Cr}_{2} \mathrm{O}_{3}$ in the feed and faeces, respectively.

Proximate composition and phosphorus concentration of the whole body, experimental diets and faeces were analysed using standard methods (AOAC 2000).

\subsection{Statistical Analysis}

The final live weight, specific growth rate, live weight gain, feed conversion ratio, survival rates of $P$. hypophthalmus fish were all subjected to one-way analysis of variance (ANOVA) to determine if significant differences occurred among the dietary treatments. The data are statistically analyzed with one-way ANOVA and Duncan's multiple range tests. Effects with a probability of $P<0.05$ were considered significant. Statistical analyses were performed using SPSS for Windows (Standard Version 9.0 SPSS Inc.).

\section{Result}

\subsection{Feed Formulation and Proximate Analysis}

The five experimental feeds had the feed formulation and proximate analysis presented in table 3 .

All five diets had the same levels of crude protein (29.28\%-30.42\%), crude lipid (5,4\%-5.7\%), fiber $(4.62 \%-4.99 \%)$ and they are not so different from the designed levels of protein (28\%) and lipid (6\%). In addition, the ash content and phosphorus and calcium phosphorus in T1 diet were higher than those in other diets (T2,T3, T4 and T5). Other feed additives such as phytase, xylanase, glucanase and acidifier were not analyzed.

Table 3. The feed formulation and feed analysis of five experimental diets

\begin{tabular}{|c|c|c|c|c|c|}
\hline Treatment & T1 & $\mathbf{T} 2$ & T3 & T4 & T5 \\
\hline Defatted rice bran & 10.00 & 10.00 & 10.00 & 10.00 & 10.00 \\
\hline Rice bran & 20.60 & 22.30 & 22.29 & 22.28 & 22.27 \\
\hline Fishmeal & 5.00 & 5.00 & 5.00 & 5.00 & 5.00 \\
\hline Soybean meal & 45.70 & 45.20 & 45.21 & 45.22 & 45.23 \\
\hline Fish oil & 2.10 & 2.10 & 2.10 & 2.10 & 2.10 \\
\hline Cassava meal & 15.00 & 15.00 & 15.00 & 15.00 & 15.00 \\
\hline DCP & 1.20 & - & - & - & - \\
\hline DL-Methionine & 0.15 & 0.15 & 0.15 & 0.15 & 0.15 \\
\hline Premix & 0.25 & 0.25 & 0.25 & 0.25 & 0.25 \\
\hline \multicolumn{6}{|c|}{ Proximate analysis of nutrient (\% dry matter) } \\
\hline Moisture (\%) & 8.12 & 7.67 & 8.61 & 7.89 & 8.89 \\
\hline Crude lipid (\%) & 5.40 & 5.49 & 5.11 & 5.70 & 5.46 \\
\hline Crude protein (\%) & 30.15 & 29.74 & 30.42 & 29.28 & 29.87 \\
\hline Ash (\%) & 8.84 & 8.12 & 8.08 & 8.31 & 8.08 \\
\hline Fiber $(\%)$ & 4.62 & 4.79 & 4.46 & 4.99 & 4.62 \\
\hline Phosphorus (\%) & 1.12 & 1.03 & 1.03 & 1.00 & 1.02 \\
\hline Calcium (\%) & 2.73 & 2.60 & 2.43 & 2.48 & 2.56 \\
\hline
\end{tabular}

T1: Positive control; T2: Negative control (reduced byDCP); T3: T2 sprayed with 0.3\% Amasil ${ }^{\circledR}$ NA (3 kg/MT); T4:T2 sprayed with Natuphos ${ }^{\circledR} 5000$ CombiL (150g/MT feed); T5: T2 sprayed with Natuphos ${ }^{\circledR} 5000$ Combi L (150g/MT feed) + 0.3\%Amasil® NA(3 kg/MT)

Premix composition (nutrient in $1 \mathrm{~kg}$ premix):

Vitamin: Retinol palmitate (Vitamin A): 1400000 UI; Cholecalciferol, (Vitamin D): 200000 UI; Alpha tocopherol acetate, (Vitamin E): 14000 mg; Niacin: 8 000mg; Pantothenic acid: 3000 mg; Riboflavin (Vitamin B2): $1400 \mathrm{mg}$; Pyridoxine (Vitamin B6): $1200 \mathrm{mg}$; Thiamine (Vitamin B1): 1200 $\mathrm{mg}$; Ascorbic acid (Vitamin C): $200 \mathrm{mg}$

Minerals: $\mathrm{FeSO}_{4} \cdot \mathrm{H}_{2} \mathrm{O}: 10000 \mathrm{mg}$; $\mathrm{ZnO}: 6000 \mathrm{mg} ; \mathrm{MnO}: 4000 \mathrm{mg} ; \mathrm{CuSO}_{4} \_5 \mathrm{H}_{2} \mathrm{O}: 600 \mathrm{mg}$ and $\mathrm{CaCO}_{3}$ as carrier. 


\subsection{Water Quality of Culture Tanks}

Water was sampled twice a day in the morning (6.30 am) and in the afternoon (14.00) for Dissolved oxygen (DO), $\mathrm{pH}$ and water temperature analysis. For total ammonia samples, it was sampled only in the morning since there is not different in the morning and in the afternoon.

In the Table 4, the water DO of tanks in the morning was $3.50 \mathrm{mg} / \mathrm{l}$ on average but sometimes it dropped to the lowest level of $1.05 \mathrm{mg} / \mathrm{l}$. However, tra catfish is an air-breathing fish species that can survive at very low oxygen in the water. Such low oxygen level in fish pond did not affect to the fish growth and survival rates.

However, water DO in the afternoon was always higher than those in the morning especially values in the afternoon $(15 \mathrm{mg} / \mathrm{l})$ since the water was daily exchanged from an outdoor earthen pond which algae development in fishpond supplied oxygen during the daytime.

Water tank $\mathrm{pH}$ values varied 6.56-7.08 in the morning and 6.96-7.89 in the afternoon. The higher $\mathrm{pH}$ value in the afternoon since the supplied water from an earthen pond. That value is suitable for fish growth.

Water tank temperature varied $26.6-28.9^{\circ} \mathrm{C}$ in the morning and $27.4-32.9^{\circ} \mathrm{C}$ in the afternoon. Such temperature is suitable for tropical fish species like tra catfish

Total ammonia of tank water was lowest at $0.05 \mathrm{mg} / \mathrm{l}$ at the beginning of the feeding trial and increased to the maximal value of $0.55 \mathrm{mg} / \mathrm{l}$ at the end of the trial. The high total ammonia was in the suitable range for fish.

\subsection{Growth Performances and Feed Utilization}

The growth performances (specific growth rates and final weight) and feed utilization of fish fed five diets in 10 weeks were presented in Table 5 .

The fish survival rates after 10 weeks of feeding are ranged $98.33 \%$ to $99.44 \%$ and not significantly different among treatments. Such survival rates are white high and showed that the feed additive supplementation does not have any effect to the survival rates.

The final weight after feeding experimental diets in Table 5 indicated the T2 treatment has the lowest final weight when compared to other treatments (T1, T3, T4 and T5) and a significant difference of $\mathrm{T} 2$ treatment $(105.17 \mathrm{~g})$ from to the T5 treatment (126.76 g) was observed. The same trend was recognized in other growth performances: specific growth rates $\left(\%\right.$ day $\left.^{-1}\right)$ which has the lowest values at the T2 treatment $\left(2.69 \%\right.$.day $\left.^{-1}\right)$ and significant difference from the T5 treatment $\left(2.96 \%\right.$. day $\left.^{-1}\right)$ but it is not significant different from the T1,T3 and T4 treatments.

For feed utilization, the feeding intake (g/fish/day) of fish fed five diets are in the range of 1.66 to $1.83 \mathrm{~g} / \mathrm{fish} / \mathrm{day}$. That is not significantly different. For feed conversion ratio (FCR), the T2 treatment has the highest value (1.23) compared to other treatments (T1, T3, T4 and T5). However, there are not significantly different among treatments in term of FCR.

Table 4. Dissolved oxygen (DO), $\mathrm{pH}$, temperature and total ammonia of water in tanks

\begin{tabular}{|c|c|c|c|}
\hline \multicolumn{1}{|c|}{ Dissolved oxygen $(\mathrm{mg} / \mathrm{l})$} & Maximum & Minimum & \\
\hline \multicolumn{2}{|c|}{} & & \\
\hline in the morning & 5.95 & 1.05 & 11.27 \\
\hline -in the afternoon & 15.20 & 7.34 & \\
\hline pH value & & & 6.82 \\
\hline in the morning & 7.08 & 6.56 & 7.425 \\
\hline in the afternoon & 7.89 & 6.96 & \\
\hline Temperature & & & 27.75 \\
\hline in the morning & 28.9 & 26.6 & 30.15 \\
\hline in the afternoon & 32.9 & 27.4 & 0.25 \\
\hline Total ammonia (mg/l) & 0.05 & 0.45 & \\
\hline
\end{tabular}

Table 5. Growth performances and feed utilization of fish

\begin{tabular}{|c|c|c|c|c|c|}
\hline Treatments & T1 & $\mathbf{T 2}$ & T3 & T4 & T5 \\
\hline Initial weight $(\mathrm{g})$ & $15.90^{\mathrm{a}} \pm 0.11$ & $15.98^{\mathrm{a}} \pm 0.04$ & $15.92^{\mathrm{a}} \pm 0.10$ & $16.01^{\mathrm{a}} \pm 0.02$ & $15.97^{\mathrm{a}} \pm 0.01$ \\
\hline Final weight $(\mathrm{g})$ & $110.68^{\mathrm{ab}} \pm 5.39$ & $105.17^{\mathrm{a}} \pm 1.03$ & $122.04^{\mathrm{ab}} \pm 5.93$ & $123.37^{\mathrm{ab}} \pm 8.65$ & $126.76^{\mathrm{b}} \pm 4.71$ \\
\hline Specific growth rate (SGR): \%.day ${ }^{-1}$ & $2.76^{\mathrm{ab}} \pm 0.06$ & $2.69^{\mathrm{a}} \pm 0.02$ & $2.91^{\mathrm{ab}} \pm 0.13$ & $2.92^{\mathrm{ab}} \pm 0.15$ & $2.96^{\mathrm{b}} \pm 0.05$ \\
\hline Survival rates $(\%)$ & $98.89^{\mathrm{a}} \pm 1.11$ & $98.33^{\mathrm{a}} \pm 0.55$ & $98.89^{\mathrm{a}} \pm 0.64$ & $98.33^{\mathrm{a}} \pm 1.66$ & $99.44^{\mathrm{a}} \pm 1.11$ \\
\hline Feeding intake (g/fish/day) & $1.65^{\mathrm{a}} \pm 0.10$ & $1.66^{\mathrm{a}} \pm 0.10$ & $1.82^{\mathrm{a}} \pm 0.20$ & $1.72^{\mathrm{a}} \pm 0.24$ & $1.74^{\mathrm{a}} \pm 0.15$ \\
\hline Feed conversion ratio (FCR) & $1.22^{\mathrm{a}} \pm 0.01$ & $1.23^{\mathrm{a}} \pm 0.03$ & $1.21^{\mathrm{a}} \pm 0.00$ & $1.22^{\mathrm{a}} \pm 0.04$ & $1.21^{\mathrm{a}} \pm 0.01$ \\
\hline
\end{tabular}

Mean \pm standard deviation: Number in the same line having the same superscript letter were not significantly different $(\mathrm{P}>0.05 \%)$ 
The Use of Phytase and Acidifier Supplementation

on Growth and Feed Utilization of Tra Catfish (Pangasianodon hypophthalmus)

Table 6. The whole fish and fish bone analysis (\% dry matter)

\begin{tabular}{|c|c|c|c|c|c|}
\hline Treatment & T1 & $\mathbf{T 2}$ & T3 & T4 & T5 \\
\hline \multicolumn{6}{|l|}{ Whole fish composition } \\
\hline Dry matter (\%) & $30.97^{\mathrm{ab}} \pm 1.55$ & $28.56^{\mathrm{a}} \pm 1.52$ & $31.07^{\mathrm{ab}} \pm 2.25$ & $32.18^{\mathrm{b}} \pm 1.31$ & $31.87^{\mathrm{b}} \pm 2.68$ \\
\hline Crude lipid (\%) & $27.50^{\mathrm{a}} \pm 1.13$ & $24.93^{\mathrm{a}} \pm 1.53$ & $25.50^{\mathrm{a}} \pm 1.03$ & $25.06^{\mathrm{a}} \pm 3.93$ & $25.88^{\mathrm{a}} \pm 1.51$ \\
\hline Crude protein (\%) & $48.24^{\mathrm{a}} \pm 5.57$ & $48.04^{\mathrm{a}} \pm 0.96$ & $48.24^{\mathrm{a}} \pm 2.37$ & $48.19^{\mathrm{a}} \pm 4.92$ & $51.13^{\mathrm{a}} \pm 2.48$ \\
\hline Carcass ash (\%) & $19.85^{\mathrm{b}} \pm 1.01$ & $16.58^{\mathrm{a}} \pm 0.99$ & $17.30^{\mathrm{ab}} \pm 2.11$ & $19.65^{\mathrm{b}} \pm 1.51$ & $17.92^{\mathrm{ab}} \pm 1.43$ \\
\hline \multicolumn{6}{|l|}{ Fish bone analysis } \\
\hline Bone ash $(\%)$ & $40.47^{\mathrm{a}} \pm 3.53$ & $37.29^{\mathrm{a}} \pm 5.97$ & $40.89^{\mathrm{a}} \pm 0.76$ & $41.65^{\mathrm{a}} \pm 3.31$ & $40.10^{\mathrm{a}} \pm 2.98$ \\
\hline Bone calcium (\%) & $14.60^{\mathrm{a}} \pm 0.71$ & $13.95^{\mathrm{a}} \pm 1.19$ & $14.46^{\mathrm{a}} \pm 0.28$ & $14.24^{\mathrm{a}} \pm 0.63$ & $14.01^{\mathrm{a}} \pm 0.46$ \\
\hline Bone phosphorus (\%) & $7.39^{\mathrm{a}} \pm 0.35$ & $7.17^{\mathrm{a}} \pm 0.48$ & $7.59^{\mathrm{a}} \pm 0.08$ & $7.72^{\mathrm{a}} \pm 0.38$ & $7.45^{\mathrm{a}} \pm 0.29$ \\
\hline
\end{tabular}

Mean \pm standard deviation: Number in the same line having the same superscript letter were not significantly different $(\mathrm{P}>0.05 \%)$

Table 7. Apparent digestibility coefficient (ADC) of dry matter, phosphorus and protein (\%)

\begin{tabular}{|c|c|c|c|c|c|}
\hline Treatments & T1 & T2 & T3 & T4 & T5 \\
\hline Dry matter & $80.45^{\mathrm{a}} \pm 1.25$ & $79.32^{\mathrm{a}} \pm 1.89$ & $78.01^{\mathrm{a}} \pm 2.16$ & $80.12^{\mathrm{a}} \pm 1.23$ & $81.35^{\mathrm{a}} \pm 0.98$ \\
\hline Protein & $84.54^{\mathrm{a}} \pm 3.45$ & $83.87^{\mathrm{a}} \pm 2.41$ & $83.12^{\mathrm{a}} \pm 1.78$ & $85.21^{\mathrm{a}} \pm 2.14$ & $85.2^{\mathrm{a}} \pm 1.94$ \\
\hline Phosphorus & $56.12^{\mathrm{a}} \pm 4.12$ & $52.1^{\mathrm{a}} \pm 3.48$ & $64.34^{\mathrm{ab}} \pm 4.23$ & $72.14^{\mathrm{b}} \pm 4.58$ & $75.2^{\mathrm{b}} \pm 4.56$ \\
\hline
\end{tabular}

Mean \pm standard deviation: Number in the same line having the same superscript letter were not significantly different $(\mathrm{P}>0.05 \%)$

\subsection{The Fish Carcass Composition at the End of the Experiment}

At the end of the experiment, the whole fish and the fish bone were analyzed and presented in the table 6 .

In the Table 6, the dry matter was lowest at the T2 treatment and significantly different from the T4 and T5 treatment but it was not significantly different from the $\mathrm{T} 1$ and T3 treatment. Carcass ash had the same tendency and the T2 treatment has the lowest value compared to other treatments. Crude lipid and crude protein of the whole body of five treatments were not significantly different $(\mathrm{P}>0.05)$.

In fish bone composition, the ash, calcium and phosphorus content had the lowest value at the T2 treatment but they are not significantly different from other treatments.

\subsection{The Digestibility}

At the end of the feeding trial, fish continued to feed with experimental feed mixed with chromic oxide as a marker for digestibility test. The apparent digestibility coefficient (ADC) of dry matter and nutrient were presented in the table 7 .

The ADC of dry matter and protein in table 7 was not significantly different among 5 treatments. Meanwhile the ADC of phosphorus had the lowest value at the T1 and T2 treatments and was significantly different from the T4 and $\mathrm{T} 5$ treatments. It is clear that the T4 and T5 phosphorus digestibility was significantly improved compared to T1 and T2.

\section{Discussion}

In the study the five diets have same nutrient composition (protein, lipid, fat) except the ash and phosphorus content (Table 3) where T1 treatment is higher than other treatments (T2, T3, T4, T5).

The growth performance in $\mathrm{T} 1, \mathrm{~T} 3$ and $\mathrm{T} 4$ have a tendency of higher performances than those in $\mathrm{T} 2$; whereas that parameter was significantly improved in T5 when compared to $\mathrm{T} 2$.

FCR was not significantly influenced by any treatment. That indicates the phosphorus supplementation in tra catfish improves growth performances, lightly ameliorate feed utilization and increases dry matter and ash content of fish body.

Available phosphorus requirements of the channel catfish (Ictalurus punctatus) were estimated to be $0.3-0.34 \%$ for fingerling and sub-adult [7]. Phosphorus requirements of juvenile tra catfish have not been determined, but it seems that available phosphorus requirement of the fish could be as high as around $0.65-0.6 .6 \%$ [11].

The study also indicates that dietary supplementation of the enzyme phytase at a dosage of $750 \mathrm{FTU} / \mathrm{kg}$ feed (T4 and T5) significantly improved growth performance of juvenile tra catfish, ameliorated feed utilization and increased ash content of the whole body and bone phosphorus. It is obvious that phytase supplementation in the study had a positive effect on releasing bound phosphorus in the diets. Hung et al. (2015) also found the fungal phytase at the dosage of $750-1500 \mathrm{FTU} / \mathrm{kg}$ can replace the DCP supplementation in tra catfish feed.

Phytase is an enzyme that can hydrolyses indigestible phytate. Up to $80 \%$ of the total phosphorus content in plant protein sources is practically not available for fish as they do not have an endogenous phytase enzyme in their 
digestive tract $[2,5,8,9,17]$. The same result was observed for catfish [6, 13]; tilapia [18]; common carp [19] and rohu [3].

The study indicates that the supplementation of non-corrosive acidifier (Amasil ${ }^{\circledR} \mathrm{NA}$ ) at a dosage of $150 \mathrm{~g} / \mathrm{MT}$ of feed (T3) also improved growth performance of juvenile tra catfish, ameliorated feed utilization and increased ash content of the whole body and bone phosphorus. Except for phosphorus even all digestibility parameters were improved by that treatment to the same level as it was found for the enzyme supplemented group (T4). The decreased $\mathrm{pH}$ value of gastric juice due to the acidifier supplementation in tra catfish can accounts for the present result to increase growth performances and feed utilization.

The study also indicates the mixture of enzyme phytase (Natuphos ${ }^{\circledR} 5000$ Combi L) and a non-corrosive acidifier (Amasil ${ }^{\circledR}$ NA) does not have any ameliorated effect when compared to the separated phytase or separated acidifier with respect to fish performance and body composition. A synergistic effect of the combination could not be demonstrated in the present study. Even there is an interaction of phytase and citric acid on the utilization of phosphorus by common carp (Cyprinus carpio) [19]. Further investigation is needed in order to find out the mode of action and probably the optimal suitable mixture for tra catfish feeds.

\section{Conclusions}

Supplementation of enzyme phytase (Natuphos ${ }^{\circledR} 5000$ Combi L) and acidifier (Amasil ${ }^{\circledR}$ NA) in tra catfish diet containing high level of plant protein sources significantly increased growth performances, feed efficiency and dry matter and ash content of the fish when compared to the control. There are no significant differences in growth performances and feed utilization when enzyme supplemented group is compared to DCP supplemented control. The data suggests that supplementing enzyme preparation of phytase and an acidifier can completely replace DCP or other phosphorus sources in tra catfish feed and potentially reduce the phosphorus discharge into the environment.

\section{REFERENCES}

[1] Adeola, O. \&Cowieson, A.J. (2011) Board - invited review: Opportunities and challenges in using exogenous enzymes to improve non-ruminant animal production. J. Animal Sci., 89(10):3189-218

[2] AOAC (2000) Association of official analytical chemists. Official Methods of Analysis (Horwitz, W. ed.), 17th edn., AOAC, Maryland, USA.
[3] Baruah, K., Sahu, N.P., Pal, A.K. \&Debnath, D. (2004) Dietary Phytase: An ideal approach for a cost effective and low-polluting aquafeed. NAGA, World Fish Center Quarterly, 27: 15-19.

[4] Baruah, K., Pal, A.K., Sahu, N.P. \&Debnath, D. (2007) Microbial phytase supplementation in rohu, Labeo rohita, diets enhances growth performance and nutrient digestibility. J. World Aquac. Soc., 38: 129-137.

[5] Cao, L., Wang, W., Yang, C., Yang, Y., Diana, J., Yakupitiyage, A., Luo, Z. \& Li, D. (2007) Application of microbial phytase in fish feed. Enzyme Microbial Technol., 40: 497-507.

[6] Cao, L., Yang, Y., Wang, W.M., Yakupitiyage, A., Yuan, D.R. \& Diana, J.S. (2008) Effects of pre-treatment with microbial phytase on phosphorous utilization and growth performance of Nile tilapia (Oreochromis niloticus). Aquac. Nutr.,14: 99-109.

[7] Cho, C.Y., Slinger, S.J. \&Bayley, H.S. (1982) Bioenergetics of salmonid fishes: energy intake, expenditure and productivity. Comp. Biochem. Physiol. B Biochem. Mol. Biol., 73: 25-41.

[8] Debnath, D., Pal, A.K. \& Sahu, N.P. (2005a) Effect of dietary microbial phytase supplementation on growth and nutrient digestibility of Pangasius pangasius (Hamilton) fingerlings. Aquacult. Res., 36: 180-187.

[9] Eya J.C. \& Lovell R.T. (1997) Available phosphorus requirement of food sized channel catfish fed practical diets in ponds. Aquaculture: 154: 283-291.

[10] Francis, G., Makkar, H.P.S. \& Becker, K. (2001) Anti-nutritional factors present in plant-derived alternate fish feed ingredients and their effects in fish. Aquaculture, 199: 197-227.

[11] Greiner, R. \&Konietzny, U. (2006) Phytase for food application. Food Technol. Biotechnol., 44: 125-140.

[12] Hung L.T.\&Huy H.P.V. (2007) Analysis of feeds and fertilizers for sustainable aquaculture development in Viet Nam 331-363. In: Hasan et al. (eds.) Study and Analysis of Feeds and Fertilizers for Sustainable Aquaculture Development, FAOFisheries Technical Paper, 497. FAO, Roma, 2007. 510p.

[13] Hung L.T, N.T. Thanh, P.M. Anh, C.L. Browdy (2015). A comparison of the effect of dietary fungal phytase and dicalcium phosphate supplementation on growth performances, feed and phosphorus utilization of tra catfish juveniles (Pangasianodon hypophthalmus Sauvage, 1878). Aquaculture Nutrition: Volume 21, Issue 1: 10-17

[14] Jackson, L.S., Li, M.H. \& Robinson, E.H. (1996) Used of microbial phytase in channel catfish Ictalurus punctatus diets to improve utilization of phytate phosphorus. J. World Aquacult. Soc.,27: 309-313.

[15] Kim, T.N.T \& Hung, L.T. (2007) Study of phytase effect on growth performance and feed utilization for basa catfish (Pangasius bocourti).Nong Lam J. Sci. Technol.,1 \& 2:156-161.

[16] Kumar, V., Sinha, A.K., Makkar, H.P.S., Boeck, G.D. \& Becker, K. (2011) Phytate and phytase in fish nutrition. J. Anim. Physiol. Anim. Nutr. 96: 335-364. doi: 
10.1111/j.1439-0396.2011.01169.x

[17] Li, M.H. \& Robinson, E.H., (1997) Microbial phytase can replace inorganic phosphorus supplements in channel catfish Ictalurus punctatus diets. J. World Aquacult. Soc., 28: 402-406.

[18] Liebert, F. \&Portz, L. (2007) Different sources of microbial phytase in plant based low phosphorus diets for Nile tilapia Oreochromis niloticus may provide different effects on phytate degradation. Aquaculture, 267: 292-299.

[19] NRC (National Research Council) (1993) Nutrient Requirements of Fish. National Academy Press, Washington, DC, USA.

[20] Phromkunthong, W. \&Gabaudan, J. (2006) Used of microbial phytase to replace inorganic phosphorus in sex-reversed red tilapia: 1 dose response. Songklanakarin J. Sci. Technol., 28: 731-743.

[21] Phromkunthong, W., Nuntapong, N. \&Gabaudan, J. (2010) Interaction of phytase RONOZYME®P(L) and citric acid on the utilization of phosphorus by common carp (Cyprinus carpio). Songklanakarin J. Sci. Technol., 32: 547-554.

[22] Rodehutscord, M. \&Pfeffer, E. (1995) Effects of supplemental microbial phytase on phosphorus digestibility and utilization in rainbow trout (Oncorhynchus mykiss). Water Sci. Technol., 31: 143-147.

[23] Sardar, P., Randhawa, H.S., Abid, M. \&Prabhakar, S.K. (2007) Effect of dietary microbial phytase supplementation on growth performance, nutrient utilization, body compositions and haematsbio chemical profiles of Cyprinus carpio (L.) fingerlings fed soy protein-based diet. Aquac. Nutr., 13: 444-456.

[24] Schafer, A., Koppe, W.N., Megerburgdorff, K.H. \& Gunther, K.D. (1995) Effects of a microbial phytase on the utilization of native phosphorus by carp in a diet based on soybean meal. Water Sci. Technol., 31: 149-155.

[25] VASEP (Vietnamese Association of Exporters and Producers, 2011). Annual Report of the Year 2010. Ho Chi Minh City, Vietnam. 